\title{
ENTRE A HESITAÇÃO E A AÇÃO: A SUBJETIVIDADE MELANCÓLICA NA ORIGEM DO DRAMA BARROCO ALEMÃO
}

\author{
Márcio Jarek*
}

Resumo: A melancolia, que influenciou o estado de espírito de muitas épocas, veio a ser determinante nos humores do Barroco do século XVII e marcaria, ao longo dos últimos séculos, uma subjetividade carregada de contradições, ora proporcionando a apatia, a hesitação e a inércia, ora provocando a constituição de elementos de ação e de visão crítica por intermédio da linguagem de múltiplas significações da alegoria. Nessa mesma perspectiva, a análise benjaminiana do drama barroco alemão, serviu de base para a constituição de um método inovador de pesquisa filosófica e que pode contribuir decisivamente para a compreensão "monadológica" dos conteúdos de verdade dispersos na realidade histórica.

Palavras-chave: Melancolia, Barroco, Alegoria, Literatura, Walter Benjamin.

\begin{abstract}
The melancholy, which influenced the state of spirit of different ages, were determinant to change the moods in the Baroque of the 17th century and would mark throughout the last centuries, a subjectivity filled with contradictions, sometimes providing apathy, hesitation and inertia, sometimes causing the constitution of elements of action and critical view through the language of multiple meanings of allegory. In this perspective, the Benjamin's analysis of the German baroque drama served as a basis for the constitution of a novel method of philosophical research which may contribute decisively for the "monodological" understanding of the truth contents dispersed in historical reality.
\end{abstract}

Keywords: Melancholy, Baroque, Allegory, Literature, Walter Benjamin.

\footnotetext{
Mestre em Filosofia pela Pontifícia Universidade Católica do Paraná - PUCPR. E-mail: m.jarek@hotmail.com
} 
"[...] O espírito que vi talvez seja um demônio.

Pois o demônio tem poder para assumir

aspecto sedutor: talvez se prevaleça

desta melancolia e deste abatimento,

já que tem força sobre os espiritos assim [...]

A consciência do rei se trairá com a peça."

(Shakespeare, Hamlet, 2, II.)

\section{A obra Origem do Drama Barroco Alemão}

Origem do Drama Barroco Alemão é a obra que termina, antes de seu início, a carreira universitária do filósofo berlinense Walter Benjamin. Após ter percorrido o universo kantiano no início de seus estudos na Suíça, refugiando-se assim da $1 .^{\circ}$ Guerra Mundial (1914-1918) e também após ter se doutorado na Universidade de Berna com trabalho sobre $O$ Conceito de Crítica de Arte no Romantismo Alemão (1920), Benjamin, pressionado por dificuldades financeiras, decide, em 1923, concorrer à livre-docência em uma universidade alemã.

O primeiro passo para uma carreira universitária, um desejo apresentado por Benjamin já em $1916^{1}$, seria a apresentação de uma Habilitation, uma tese de livredocência com o objetivo de se tornar professor titular (em alemão, Ordinarius) de uma universidade $^{2}$. A escolha de Benjamin foi a Universidade Johann Wolfgang Von Goethe de Frankfurt am Main e baseou-se no fato de ser uma instituição nova, liberal e mais aberta do que as demais para pesquisadores judeus. Baseou-se também no fato de possuir ali alguns conhecidos. Entretanto, essa escolha, bem como a escolha do tema de seu trabalho, todas guiadas pelo entusiasmo e por impulsos nada convenientes à comunidade acadêmica da época ${ }^{3}$, custaram a Benjamin mais um fracasso e um exemplo de sua constante falta de jeito e má sorte.

Hannah Arendt observa que foi o artigo sobre as Afinidades Eletivas de Goethe, produzido por Benjamin e publicado em 1924 por Hugo Von Hofmannsthal na revista Neue Deutsche Beiträge, que arruinou sua única oportunidade de ingressar na carreira universitária. Afirma ela que:

\footnotetext{
Como ocorre com freqüência nos textos de Benjamin, esse estudo (sobre as Afinidades Eletivas de Goethe) era inspirado pela polêmica, e o ataque se referia ao livro de Friedrich Gundolf sobre Goethe. (...) a única coisa que não deveria ter feito era uma escalada contra o membro acadêmico mais proeminente e capaz daquele círculo (o influente círculo de Stefan George), de modo tão veemente
}

\footnotetext{
${ }^{1}$ Cf. BUCK-MORSS, Susan. A Dialética do Olhar. Walter Benjamin e o trabalho das passagens. p. 31.

"Já em 1916 Benjamin teria dito a Scholem que 'via seu futuro numa docência de filosofia"”.

${ }^{2}$ Cf. KONDER, Leandro. Walter Benjamin: o marxismo da melancolia. p. 24.

${ }^{3}$ Cf. BUCK-MORSS, Susan. Ibid., p. 31.
} 
Benjamin não conhecia o jogo das políticas acadêmicas de sua época e até, ingenuamente, não fazia opções mais tradicionais, acreditando na derrocada da ordem burguesa que influenciava o pensamento da Alemanha nesse período ${ }^{5}$.

Desta maneira, nem mesmo a autoridade do editor Hofmannsthal poderia alterar o futuro da carreira universitária de Benjamin. O poder da escola de Stefan Georg era muito efetivo entre diversas entidades que mantinham entre si certa "fidelidade ideológica" e familiaridade em "manobras literárias", aspectos que, em julho de 1925, foram decisivos para a rejeição do trabalho de Benjamin na Universidade de Frankfurt. Esse aspectos são duramente criticados por Hannah Arendt:

\begin{abstract}
Apesar de afetarem se situar acima da política, os discípulos de Georg estavam tão intimamente familiarizados com os princípios básicos das manobras literárias quanto os professores o estavam com os rudimentos da política acadêmica, ou os escritores por encomenda e jornalistas com o abecê do "um bom favor merece outro". 6
\end{abstract}

Assim, passando de departamento a departamento, a tese de Benjamin foi recusada pelo professor Franz Schultz do Departamento de Literatura Alemã e rejeitada pelos professores Hans Cornelius e Rudolf Kautzsch do Departamento de Estética. Segundo eles, a tese definitivamente não preenchia os requisitos imprescindíveis para ser acolhida pela instituição ${ }^{7}$.

Mesmo em estudos recentes, o livro sobre o Barroco não recebe a qualidade de um trabalho de "ciência literária". Nas pesquisas especializadas sobre o gênero Barroco, a obra de Walter Benjamin é, por vezes, ignorada ou diminuída. ${ }^{8}$ Quem dirá ser aceito na República Weimar em um período de franca tentativa de restauração do Classicismo. Willi Bolle comenta que, nos anos que se seguiram após a $1^{\text {a }}$ Guerra Mundial, prevaleceu na Alemanha uma recalcada tradição clássica e classicista e que Benjamin, com sua obra sobre o Barroco, posicionava-se contra essas "teorias idealizadoras, que se recusaram a repensar a tradição humanista à luz da barbárie, da violência e do caos dos Tempos Modernos"9. Berlim, enquanto metrópole moderna, tentava assentar-se sobre um recalcado padrão cultural setecentista e palaciano, tentando se restabelecer o mundo de Goethe e Schiller. Buck-Mors comenta que até mesmo as recém retomadas Olimpíadas modernas eram parte da ideologia neoclassicista. Descrevendo uma comparação utilizada por Benjamin em uma nota ao trabalho A obra de arte na era de sua reprodutibilidade técnica (1936), Buck-Morss caracteriza a perspectiva reacionária dos jogos olímpicos modernos e que, de certa forma, explica a exaltação de Hitler dos jogos de Berlim em 1936. Segundo ela, as Olimpíadas se comparam...

\footnotetext{
${ }^{4}$ ARENDT, Hannah. Homens em Tempos Sombrios (Trad. Denise Bottmann), São Paulo, Companhia das Letras, 1987, p. 139-40. Comentários nossos.

${ }^{5}$ Cf. BUCK-MORSS, Susan. A Dialética do Olhar. Walter Benjamin e o trabalho das passagens. p. 32

${ }^{6}$ ARENDT, Hannah. Opus cit, p. 140.

${ }^{7}$ Cf. KONDER, Leandro. Walter Benjamin: o marxismo da melancolia. p. 24.

${ }^{8}$ Cf. BOLLE, Willi. Fisiognomia da Metrópole Moderna. p. 106.

${ }^{9}$ Idem, p. 109.
} 


\begin{abstract}
(...) à ciência industrial do taylorismo que empregava o cronômetro para analisar detalhadamente as ações corporais dos trabalhadores, com o propósito de fixar normas para a produtividade trabalhadora na produção mecânica. Essa era precisamente uma característica distinta das novas Olimpíadas - daí que o pretendido acontecimento antigo se revelara absolutamente moderno. Os atletas de Berlim corriam contra o relógio. Suas atuações eram medidas em "segundos e centímetros": "Essas medições estabelecem os recordes desportivos. A velha forma da luta desaparece [...]" Essa medição é uma forma de prova, não de competição: "nada mais típico da prova em sua forma moderna que essa medição do ser humano contra um aparelho". ${ }^{10}$
\end{abstract}

Assim, o estudo sobre o Barroco situa-se na perspectiva polêmica de uma crítica radical dos discursos totalizantes em voga nesse período. Benjamin coloca "o Barroco como o antagonista soberano do Classicismo" 11.

Mas o que realmente motivou Benjamin a discorrer sobre peças de teatro escritas por autores alemães do século XVII que, em geral, são conhecidas por poucos especialistas e que sequer foram encenadas alguma vez?

Talvez a melhor resposta para esta pergunta seja o comentário que Benjamin fez em uma discussão a respeito de sua obra, na cidade de Capri, no ano de 1924 e que, posteriormente, foi registrada por Asja Lacis no livro Revolutionär im Beruf. Comenta Lacis que, após ser questionado sobre os objetivos de seu trabalho, Benjamin disse-lhe que:

Primeiro, estou trazendo para a disciplina da estética
uma nova terminologia. Na discussão
contemporânea do drama, os termos tragédia e
drama trágico são usados indiscriminadamente,
somente como palavras. Mostro a diferença
fundamental entre [elas...]. Os dramas do barroco
expressam desespero e desprezo pelo mundo - são
realmente peças tristes. ${ }^{12}$

A expressão do "desespero e desprezo pelo mundo" - o componente de tristeza das peças do barroco - aliado a sua tentativa de restauração de novos patamares lingüísticos - possibilitou para Benjamin a criação de um método capaz de produzir uma "descrição abreviada do mundo". O trabalho sobre o Barroco habilitou Benjamin de uma poderosíssima capacidade de elaboração de uma "crítica alegórica" do colapso da cultura da República Weimar ${ }^{13}$ e, indiretamente, do colapso de certos aspectos da

\footnotetext{
${ }^{10}$ BUCK-MORSS, Susan. A Dialética do Olhar. Walter Benjamin e o trabalho das passagens. p. 389.

${ }^{11}$ BENJAMIN, W. Origem do Drama Barroco Alemão. p. 198. Apresentação e tradução Sérgio Paulo Rouanet. Brasiliense, 1984.

${ }^{12}$ LACIS. Asja. Revolutionär im Beruf. Munich: Regner \& Bernhard, 1971. p.43-44. Apud BUCKMORSS, Susan. A Dialética do Olhar. Walter Benjamin e o trabalho das passagens. p. 32.

${ }^{13}$ Cf. BUCK-MORSS, Susan. A Dialética do Olhar. Walter Benjamin e o trabalho das passagens. p. 37 e ainda cf. BOLLE, Willi. Fisiognomia da Metrópole Moderna. p. 106.
} 
natureza humana na Modernidade. Pois a alegoria, como acontece no Barroco, é uma forma de representação figurativa que transmite um significado outro que o oferecido literalmente. Deste modo o Barroco, ao qual pretendia Benjamin, ultrapassa a época na qual costuma ser encontrado nos livros de história. Isto significa dizer que certa essência do barroco persiste ao longo das épocas seguintes, influenciando a própria constituição melancólica da subjetividade e da sensibilidade moderna.

Asja Lacis comenta que naquela época Benjamin estava lendo Lukács e interessando-se pela estética materialista, mas confessa que não entendia corretamente a conexão entre a alegoria barroca e a poesia moderna pretendida por seu companheiro. Afirma ela que:

\begin{abstract}
Agora vejo como Benjamin foi perceptivo ao ver através do problema moderno da forma. Já nos anos vinte a alegoria (presente nos dramas barrocos) emerge (novamente) nas peças do 'Agit-prop' e nos dramas de Brecht (...) como um meio de expressão de inteira validade. ${ }^{14}$
\end{abstract}

Assim, a obra sobre o Barroco não era uma mera peça acadêmica de pesquisa. Ela tinha uma ligação profunda com os próprios problemas reais contemporâneos e tentava restaurar formas lingüísticas esquecidas como a do emblema, do ritual e, essencialmente, da alegoria para a compreensão dos fenômenos culturais da modernidade alemã.

Mais além, com a recusa de sua tese sobre o Barroco pela Universidade, não se reconheceu, naquele momento, sua importância como uma obra de crítica da cultura, negando-lhe assim, uma tradição que remonta a Nietzsche, com o seu $O$ Nascimento da Tragédia (1871) ${ }^{15}$. Tanto a obra de Benjamin quanto a de Nietzsche, primeiramente apresentaram-se com a rigidez do formato exigido aos trabalhos de ciência acadêmica e, então, estrategicamente formularam, a partir de segmento específico da história cultural (no caso de Nietzsche a tragédia clássica e em Benjamin as peças do Barroco alemão), as bases para a construção de uma crítica abrangente do cotidiano das sociedades atuais. Nietzsche e Benjamin, cada um a sua maneira, tentam "revelar", pelo prisma de épocas passadas, como a esfera pública atual pôde organizar-se ${ }^{16}$.

Assim, na tentativa de reconhecimento, ainda que esta obra seja de uma linguagem difícil e muito pouco transparente - para alguns pesquisadores considerada até um "livro estranho" ou um "livro maldito" 17 - demonstra-se que os avaliadores da Universidade de Frankfurt foram demasiado insensíveis. O Trauerspielbuch, "livro sobre o drama barroco", é hoje considerado entre os pesquisadores de nossa época como uma das obras de maior contribuição para a estética contemporânea, certamente fruto de apurada percepção visionária de Walter Benjamin sobre os nossos dias ${ }^{18}$ e contribuição

\footnotetext{
${ }^{14}$ Ibid., p. 44. apud. idem. p. 449. Comentários nossos.

${ }^{15}$ Cf. BOLLE, Willi. Ibid., p. 106.

${ }^{16}$ Cf. BOLLE, Willi. Idem. p. 107. Uma tentativa de aproximação (e distanciamento também) entre os pensamentos de Benjamin e de Nietzsche pode ser encontrada na coletânea de textos de Ernani Chaves, No Limiar do Moderno: Estudos sobre F. Nietzsche e W. Benjamin. Belém: Paka-Tatu, 2003.

${ }^{17}$ Cf. KONDER, Leandro. Walter Benjamin: o marxismo da melancolia. p. 25. "Origem do Drama Barroco Alemão é um livro estranho, perturbador. Jeanne-Marie Gagnebin chama-o de 'livro maldito'; e acrescenta: 'Tenta se lê-lo, não se o entende, tenta-se esquecê-lo, retorna-se a ele (...)".

${ }^{18}$ Cf. Sérgio Paulo Rouanet na apresentação de sua tradução de A Origem do Drama Barroco Alemão para o português. (Editora Brasiliense, 1984).
} 
comprovada, uma vez que o livro sobre o barroco foi essencial para a autonomia do pensamento do filósofo berlinense e também contribuiu decisivamente para a elaboração do arcabouço teórico dos pensadores da Escola Frankfurt, sobretudo a obra de Theodor W. Adorno.

Adorno e Benjamin, durante importante período, discutiram, através de correspondências e conversas, a respeito do estudo sobre o Barroco. Ambos compartilhavam o objetivo de uma "refuncionalização" dos métodos marxistas para identificação do esvaziamento das formas em meras peças de mercadorias e, por conseguinte, para o entendimento dos efeitos do modo capitalista de produção nas diversas áreas da cultura. Assim, as análises de Benjamin sobre a alegoria, contidas na obra sobre o Barroco e acrescidas de novas interpretações de Lukács, tornaram-se decisivas na obra de Adorno. Em um discurso de 1932, intitulado "A idéia da história natural", Adorno elogiou o trabalho de Benjamin sobre o Barroco e, comenta BuckMorss, que:

\begin{abstract}
Adorno aderiu de maneira entusiasta (...) não só ensinando o Trauerspiel (o drama barroco alemão) em seu seminário de filosofia como jovem professor na Universidade de Frankfurt am Main (o lugar que tinha rejeitado o livro como Habilitationsschrift de Benjamin), mas também pondo em prática uma versão materialista dialética desse método, em uma interpretação crítica de Kierkegaard (...) ${ }^{19}$
\end{abstract}

Desta maneira, a partir do final dos anos de 1960 a mesma universidade que recusara a Habilitationsschrift de Benjamin, num ato de reconhecimento do pensador berlinense, passou a aceitar, ao exemplo de Adorno, trabalhos sobre A Origem do Drama Barroco Alemão ${ }^{20}$. Entre outros aspectos, o entrelaçamento entre a alegoria barroca e a estética materialista dialética ilumina a relação existente entre os conceitos de mercadoria, mito, fetichismo, tempo e história. Mais tarde estes conceitos irão se tornar fundamentais e muito familiares a todos os pensadores da Teoria Crítica da Escola Frankfurt ${ }^{21}$.

Benjamin, através de seu estudo sobre as peças trágicas barrocas (o Trauerspiel), retoma um modo de sentir a realidade a partir do luto, com um olhar "póstumo" onde as alegorias são a única forma do melancólico "dizer" a realidade de ruínas de um tempo infernal que o cerca. O significado da alegoria acomoda-se ao mundo congelado do mito, cujas repetições compulsivas auxiliam Benjamin a vislumbrar posteriormente a ideologia do historicismo e sua proposta de um tempo sempre homogêneo ${ }^{22}$.

Para dar conta desses aspectos "saturninos" de seu método, Benjamin enfrentou diversas restrições temáticas, e até mesmo conceituais e desenvolveu uma inovadora

\footnotetext{
${ }^{19}$ Cf. BUCK-MORSS, Susan. A Dialética do Olhar. Walter Benjamin e o trabalho das passagens. p. 218.

${ }^{20}$ Cf. BOLLE. Willi. Fisiognomia da Metrópole Moderna. p. 106.

${ }^{21}$ Em certo sentido a crítica a racionalidade instrumental, ao mito do esclarecimento e à indústria cultural que permeia o livro, Dialética do Esclarecimento (1944) elaborado a partir da parceria entre Adorno e Horkheimer e que representa a pedra angular de toda a Escola de Frankfurt, possui sua pré-história nos debates e, por conseqüência no desenvolvimento conceitual, que se seguiu entre Adorno e Benjamin em relação à obra Origem do Drama Barroco Alemão. Esta é uma chave de pesquisa que merece ser melhor explorada (se já não o foi!) pois as afinidades conceituais existentes entre ambas as obras são muito significativas.

${ }^{22}$ Cf. EAGLETON, T. O Rabino marxista: Walter Benjamin In A Ideologia da Estética. p. 238.
} 
introdução teórica ao seu trabalho. Estas inovações marcaram profundamente seu pensamento e foram sendo aprimoradas ao longo de seus escritos posteriores.

\section{As "Questões Introdutórias de Crítica do Conhecimento"}

A obra Origem do Drama Barroco Alemão é composta de três partes distintas. A primeira parte é de difícil entendimento, refere-se às questões epistemológicas que oferecem grande densidade interpretativa e servem de suporte teórico para as demais partes que, respectivamente, tratam do Barroco e sua especificidade frente à tragédia clássica e da restituição da alegoria através do Barroco, imposta e revalorizada enquanto categoria estética diante do símbolo.

Conforme Sérgio Paulo Rouanet, na apresentação da tradução de Origem do Drama Barroco Alemão, podemos afirmar que as "questões introdutórias de crítica do conhecimento" da obra sobre o Barroco alemão servirão para o desenvolvimento de toda a filosofia, pensada enquanto crítica da cultura e da história, ao longo da obra de Walter Benjamin.

Pois bem, apesar das dificuldades, a presente seção deste trabalho tentará elucidar alguns pontos da primeira parte da obra sobre o Barroco e tentará contribuir para a compreensão de um objetivo maior que é a identificação, no pensamento de Benjamin, da melancolia como um elemento altamente crítico.

Pode-se dizer que a primeira parte da referida obra é destinada à exposição, por Benjamin, de uma certa Teoria do Conhecimento ${ }^{23}$ necessária à defesa de sua visão do Drama Barroco diante da visão sedimentada pela academia de sua época. Nas palavras de Benjamin...

\footnotetext{
O drama barroco alemão passou a ser visto como o reflexo deformado da tragédia antiga. (...) O drama barroco aparecia assim como uma renascença tosca da tragédia. E com isso surgia uma classificação que obscurecia de todo a compreensão dessa forma: visto como drama da Renascença, o drama barroco estava viciado, em seus traços mais característicos, por numerosos defeitos estilísticos. ${ }^{24}$
}

Comenta Benjamin que o Drama Barroco aparecia em sua época como uma renascença tosca da tragédia. Um reflexo deformado da tragédia antiga que, para $o$ gosto refinado proposto pelo Classicismo da época, parecia estranho e mesmo bárbaro. Durante longo tempo, até mesmo o termo "barroco" trazia em si um preconceito burguês em relação às obras do período seiscentista. O vocábulo "barroco" era usado pelos joalheiros desde o século XVI para designar um tipo de pérola irregular e de formação defeituosa, aliás até hoje conhecida pela mesma denominação. Assim, o Barroco era visto inicialmente como um conjunto de obras de grande imperfeição e de mau gosto. Era visto como a degeneração do Renascimento.

\footnotetext{
${ }^{23}$ Cf. Rouanet na apresentação da tradução de Origem do Drama Barroco Alemão.

${ }^{24}$ BENJAMIN, W. Origem do Drama Barroco Alemão. p. 72. (As demais notas referentes à obra Origem do Drama Barroco Alemão seguirão com a abreviatura $O D B)$.
} 
Contra esta sedimentada interpretação de influência classicista dos dramas barrocos, Benjamin teve que desenvolver uma complexa teoria do conhecimento que sustentasse seu ponto de vista. Este movimento foi decisivo para o despertar da maturidade filosófica do autor, onde se observa a integração criativa de conceitos de origem platônica, e até mesmo Kantiana (tais como os conceitos de Idéia e de Fenômeno), sendo utilizados em consonância com referências ao pensamento racionalista de Leibniz na construção de seu original método de "investigação filosófica monadológica". Com este método, a atividade do filósofo, na compreensão de Benjamin, metaforicamente passa a consistir no "recolhimento de várias pérolas", pérolas barrocas e irregulares, que serão utilizadas para a composição de um "fascinante colar de pérolas".

Segue assim que, para Benjamin, filosofar implica "platonicamente" entender todas as representações existentes. Por sua vez, representações do Universal, da ordem das idéias. As representações possibilitam a posse das "pérolas barrocas" dispersas e a sua respectiva composição conceitual a partir da irregularidade que cada uma apresenta de maneira única. Acerca desse método, escreve Benjamin que:

\begin{abstract}
Se a representação quiser afirmar-se como o verdadeiro método do tratado filosófico, não pode deixar de ser a representação das idéias. A verdade, presente no bailado das idéias representadas, esquiva-se a qualquer tipo de projeção no reino do saber. O saber é posse. ${ }^{25}$
\end{abstract}

As idéias sozinhas "não possuem vida", "esquivam-se", sem que os fenômenos as reconheçam e as circundem. Benjamin destaca que essas idéias "permanecem obscuras" ${ }^{26}$ sem a presença dos fenômenos. Já os Fenômenos são todas as Coisas existentes, compõem a ordem do particular, e estão condenados à dispersão e à morte sem a presença "salvadora" das Idéias. Desta maneira, o autor traça a mesma dicotomia platônica entre idéia e fenômeno, ou seja, entre a essência e a aparência, entretanto, lhe concede uma significativa diferença: enquanto no pensamento platônico as idéias estavam dispersas em um mundo exterior, Benjamin vai dizer que as idéias vivem em um outro habitat muito mais familiar, o da linguagem. ${ }^{27}$

Assim, Idéia e Fenômeno dependem fundamentalmente um do outro para existirem, contudo não podem ultrapassar seus limites, as suas devidas cercanias (de um lado a ordem das idéias - o universal e de outro a ordem dos fenômenos - o particular) sem o auxílio de uma função lingüística mediadora, uma ponte entre as diferentes ordens. Essa função é exercida pelo Conceito. São os conceitos que conseguem salvar os fenômenos diante das idéias e representar universalmente a estas frente à ordem do particular.

Os conceitos conseguem dividir as coisas em seus elementos constitutivos e estes, por sua vez, podem ser captados e salvos pelas idéias; em contrapartida, as idéias podem tornar-se concretas, representadas nos elementos materiais do conceito. Ou seja, o conceito exerce função mediadora na medida em que consegue fazer com que a idéia se manifeste empiricamente no fenômeno ao passo que o fenômeno tenha o seu reconhecimento conceitual de acordo com uma idéia à qual se refira. Deste modo consiste o processo que é definido por Benjamin como "Redenção Platônica":

\footnotetext{
${ }^{25} O D B$ p.51.

${ }^{26}$ Cf. $O D B$ p. 57.

${ }^{27}$ Cf. Sérgio Paulo Rouanet na apresentação de Origem do Drama Barroco Alemão. p. 16.
} 
A descoberta pode encontrar o autêntico nos fenômenos mais estranhos e excêntricos, nas tentativas mais frágeis e toscas, assim como nas manifestações mais sofisticadas de um período de decadência. A idéia absorve a série das manifestações históricas, mas não para construir uma unidade a partir delas, nem muito menos para delas derivar algo de comum. Não há nenhuma analogia entre a relação do particular com o conceito e a relação do particular com a idéia. No primeiro caso, ele é incluído sob o conceito, e permanece o que era antes - um particular. No segundo, ele é incluído sob a idéia, e passa a ser o que não era totalidade. Nisso consiste sua redenção platônica. ${ }^{28}$

A idéia oferece uma visão da totalidade através de suas "interpretações objetivas" dos fenômenos e este processo passa a ser a grande ferramenta de investigação do filósofo. Cada manifestação histórica, seja nos períodos de decadência ou de esplendor, poderá originar um autêntico, uma visão de totalidade além da história acerca dos acontecimentos. Desta maneira, cabe à investigação filosófica a análise estrutural de seus objetos e, respectivamente, do isolamento de seus elementos extremos, ou seja, da busca em cada fenômeno daquilo que o singulariza em relação aos outros. Assim, o filósofo "representando as idéias e salvando os fenômenos" conseguirá, então, descobrir a origem, a essencialidade da estrutura interna de seu objeto de estudo. Nas palavras de Benjamin...

\footnotetext{
A tarefa do pesquisador (...) se inicia aqui, pois ele não pode considerar esse (ou aquele) fato assegurado, antes que sua estrutura interna apareça com tanta essencialidade, que se revele como origem. O autêntico - o selo da origem nos fenômenos - é objeto de descoberta, uma descoberta que se relaciona, singularmente, com o reconhecimento. ${ }^{29}$
}

Esta origem, ressalta o filósofo, não tem nada que ver com a gênese. Origem designa algo que emerge do vir-a-ser e da extinção e não o vir-a-ser daquilo que se origina. Ou seja, a origem se relaciona com a totalidade com que a idéia se confronta com o mundo histórico. A origem mostra como o único e o recorrente se interrelacionam. Por essa razão, Benjamin vai considerar toda a filosofia como uma ciência da origem. Uma forma que segundo ele "permite a emergência, a partir dos extremos mais distantes e dos aparentes excessos do processo de desenvolvimento, da configuração da idéia, enquanto Todo..." 30. Assim, o método de análise estrutural oferecida por uma "ciência da origem" permite a observação da história não apenas como encadeamento de fatos, mas através da visão de totalidade da idéia, consegue verificar a pré e a pós-história, as afinidades internas, de qualquer que seja a distância

\footnotetext{
${ }^{28}$ ODB, p. 68-69.

${ }^{29}$ Ibidem, p.68.

${ }^{30}$ Idem, p. 68.
} 
que separam duas épocas, pois as estruturas das idéias, segundo Benjamin, "resultante do contraste entre seu isolamento inalienável e a totalidade, é monadológica. A idéia é mônada." 31 .

A mônada, conforme caracterizada por Leibniz, é uma substância simples, visto que não possui partes, mas constitui uma unidade simples, não-composta e indivisível. Entretanto, a qualidade das mônadas é múltipla. Sua diversidade na qualidade implica a multiplicidade de formas das coisas que compõem o mundo e faz a mônada ser uma estrutura que pode ser compreendida como uma multiplicidade contida na unidade. Deste modo, cada mônada é uma espécie de espelho vivo e perpétuo do universo, um espelho porque cada mônada é uma multiplicidade, com inúmeros compartimentos que realizam com outras mônadas relações que exprimem todo o universo. Benjamin assumirá essa definição Leibnizeana da mônada mas atribuirá a ela o status de idéia. É a idéia que é monadológica.

A compreensão monadológica do barroco, ou seja, o entendimento de sua estrutura e do barroco enquanto idéia, leva o pensador berlinense a também compreender a tragédia clássica, o drama romântico, o drama expressionista. Da mesma maneira que o inverso também é válido. A investigação da estrutura de qualquer fenômeno permite a decifração de elementos que existem na pré e na pós-história desse mesmo fenômeno. É possível capturar "tendências que aludem ao tempo, mas são em si intemporais" ${ }^{32}$, capturar as afinidades internas que se mantêm, qualquer seja a distância entre as épocas.

Dessa maneira, o procedimento proposto por Benjamin, segundo Rouanet "é trivial, mas vale como paradigma (...): leitura monadológica do particular, até que ele fale, e nessa fala revele as leis do todo." ${ }^{33}$ Cada idéia contém a imagem do mundo. Representar as idéias consiste, portanto, na difícil tarefa de descrição das imagens abreviadas do mundo, com um mergulho tão fundo em todo o real, que ele possa revelar-nos uma interpretação objetiva. Tendo em vista a característica desta tarefa, segundo Benjamin, "não surpreende que o autor da Monadologia (Leibniz) tenha sido também o criador do cálculo infinitesimal" 34.

Jean-Marie Gagnebin, no que diz respeito a mônada, aponta para duas vertentes essenciais do pensamento benjaminiano: a imersão (Versenkung) no objeto e a idéia de uma reunião, de uma recoleção (Versammlung) salvadora dos fenômenos esparsos e perdidos no instante histórico fugidio. Segundo ela:

\begin{abstract}
A atividade crítica e salvadora do pensamento exercer-se-ia, segundo Benjamin, não tanto nos amplos vôos totalizantes da razão mas, muito mais, na atenção concentrada e despojada no detalhe à primeira vista sem importância, ou então no estranho, no extremo, no desviante de que nenhuma média consegue dar conta. ${ }^{35}$
\end{abstract}

Desta maneira, a leitura da imagem do mundo através do particular propiciada pela mônada, um movimento de atenção e de concentração do pensamento em direção ao real, impede a fragilidade das pretensas visões totalizantes de conjunto e ressalta a

\footnotetext{
${ }^{31}$ Idem, p. 69.

${ }^{32}$ ROUANET, Sérgio P. Na apresentação de Origem do Drama Barroco Alemão. p. 21.

${ }^{33}$ Idem, p. 21.

${ }^{34}$ Idem, p. 70.

${ }^{35}$ GAGNEBIM, Jean-Marie. Por que um mundo todo nos detalhes do cotidiano? História e Cotidiano em Walter Benjamin. In Dossie Walter Benjamin. Revista USP. № 15 . (Versão On-line)
} 
força salvadora da restrição, da posse restrita, a mesma posse que o colecionador tem em relação ao objeto colecionado, pois o termo restrição (Beschrãnkung) possui em alemão o mesmo radical que a palavra Schrank, que significa armário e este, como sabemos, é o local preferido para a guarda de itens de uma coleção. Mais tarde o termo Schrank vai constituir o título de um dos textos centrais da obra de Benjamin Infância Berlinense por volta de 1900 (1938) ${ }^{36}$.

\section{O Trauerspiel}

Trauerspiel é uma palavra utilizada inicialmente no século XVII para denominar certo gênero da tragédia teatral próprio do período barroco alemão. A palavra tragédia (Tragödie em alemão) seria suficiente para denominar tal estilo teatral, entretanto há em Benjamin a necessidade de distinção entre Trauerspiel e Tragödie, necessidade surgida na polemização benjaminiana contra a interpretação tradicional dos críticos de sua época sobre o Barroco literário e sobre a tragédia clássica. A respeito desse aspecto, Benjamin afirma enfaticamente que:

\footnotetext{
Os comentadores sempre insistiram em reconhecer como elementos essenciais do drama barroco os elementos da tragédia grega - a fábula trágica, o herói e a morte trágica - por mais que eles tivessem sido deformados por imitadores incapazes de compreendê-los. (...) o teatro moderno não conhece nenhuma tragédia que se assemelhe à dos gregos. (...) tais teorias dão a entender, presunçosamente, que ainda hoje é possível escrever tragédias. ${ }^{37}$
}

A Alemanha do período em que Benjamin estava produzindo sua obra sobre o Barroco, procurava restabelecer um recalcado mundo classicista. A modernidade alemã inspirava-se em uma problemática padronização cultural setecentista e palaciana, elevando as figuras de Goethe e Schiller frente à lembrança da barbárie experimentada com a 1. ${ }^{a}$ Guerra Mundial. Contra este tipo de influência, recaía também o estudo sobre o barroco de Benjamin com sua necessidade de imposição até mesmo terminológica.

Tentando respeitar a polemicidade desses significados "Ursprung des deutschen Trauerspiels" foi vertido para o português como A Origem do Drama Barroco Alemão, utilizando-se o termo "Drama Barroco" para denominar o Trauerspiel. Entretanto, a utilização do termo "Drama" ainda pode provocar alguns equívocos, já que a palavra Drama também existe no alemão e é aplicada de forma genérica tanto ao Trauerspiel quanto a Tragödie. Benjamin ainda utiliza o termo Trauerspiel fazendo ocasionalmente referências a

\footnotetext{
${ }^{36}$ Idem.

${ }^{37} O D B$. p. $123-24$.
} 
gêneros pós-barrocos ${ }^{38}$

Trauerspiel pode significar, literalmente, "jogo da melancolia". O termo Spiel, significa entre outras coisas "espetáculo", "jogo", "peça" ou "encenação"; já o termo Trauer, significa "luto" e a dor decorrente desta situação, a "melancolia". Assim, podemos compor alguns jogos de palavras como "espetáculo lutuoso", "encenação de luto", "peça de melancolia", "jogo de luto", "encenação da dor do luto", "jogo da melancolia", etc. ${ }^{39}$.

A partir desta ambivalência de significados que o termo Trauerspiel proporciona, a alegoria é antecipada. A alegoria é a figura de linguagem que propicia uma representação que consegue se sustentar com a ausência de um referencial último de significação, com uma constante não-identidade, de maneira que a linguagem sempre diga algo diferente daquilo que originalmente visava. Assim o termo Trauerspiel extrai sua força da composição de seus dois fatores antitéticos (respectivamente Luto e Jogo); o luto por um referencial significante ausente e definitivamente perdido, e o jogo que esta ausência possibilita aos que conseguem suportar esta queda. No Trauerspiel dois termos opostos encontram uma única morada, entretanto nunca encontram uma síntese ou mesmo uma supervalorização de um sobre o outro, característica que marca o conflito espiritual próprio da mentalidade melancólica do período Barroco.

A respeito dessa relação entre jogo e luto, uma relação de conflito entre os sentimentos que provocam o riso e aqueles que causam as lágrimas, tão representativa do Barroco, a literatura dessa época nos traz, como exemplo, o problema colocado pela Real Academia da Rainha da Suécia em Roma e magnificamente respondido por Padre Antônio Vieira no ano de 1674. O problema proposto era o seguinte: "O que seria mais razoável, se o riso de Demócrito, que de tudo zombava, ou o pranto de Heráclito, que por tudo chorava?" ${ }^{40}$. O problema baseia-se na lenda segundo a qual Demócrito era o filósofo que ria diante da insensatez dos homens, em antítese a Heráclito, amigo da solidão, cujo estilo obscuro o aproximava da melancolia e o fazia filósofo das lágrimas. Esta lenda encarna a oposição Barroca, presente no Trauerspiel, entre a efemeridade trágica da vida em seu percurso inexorável, representada por Heráclito, e a atitude vitalista do carpe diem e do culto do prazer imediato representada pela doutrina atomista de Demócrito ${ }^{41}$.

Em Origem do Drama Barroco, Benjamin pressupõe do leitor um conhecimento factual do teatro barroco alemão ${ }^{42} \mathrm{e}$, diga-se de passagem, do barroco enquanto idéia, aspecto pouco realista para a época e que torna a obra de uma leitura muito difícil e certamente contribuiu para tornar o Trauerspielbuch um "livro estranho" e "maldito" 43. Seguindo as observações de Rouanet na apresentação da tradução da obra no Brasil, esquematicamente o teatro barroco do século XVII na Alemanha pode ser resumido como um gênero de peças que tiveram sua origem no drama jesuítico e que conservaram

\footnotetext{
${ }^{38}$ Cf. $O D B$. (nota de tradução de Sérgio Paulo Rouanet).

39 Em Luto e Melancolia (1917), Freud, contrariamente à Benjamin, faz uma sutil distinção entre o significado de luto (Trauer) e de melancolia (Melancolie). Ver seção 2.4 do presente trabalho - Antíteses sem síntese: a subjetividade melancólica.

40 A apresentação histórica do problema, a importância desta na obra do escritor barroco português Antônio Vieira (1608-1697), bem como, a resposta de Vieira no original em italiano e a tradução portuguesa de época encontram-se no livro As lágrimas de Heráclito de organização de Sônia N. Salomão.

${ }^{41}$ Idem, p. 63-64.

${ }^{42}$ Cf. ROUANET, Sérgio Paulo. Na apresentação de Origem do Drama Barroco Alemão. p. 23.

${ }^{43}$ Ver observações na nota 14.
} 
as características típicas e inerentes a instrumentos de propaganda da Contra-Reforma.

Desta maneira, para atingir seus objetivos, os autores da época recorreram a grande gama de recursos cênicos tais como: pantomimas, coros, grandes elencos, cenários com pintura em perspectiva e máquinas teatrais que permitiam a suspensão de atores para a representação de batalhas, por exemplo, entre anjos e demônios. Havia também grande quantidade de personagens de natureza alegórica que simbolizavam virtudes cristãs e, por sua vez, vícios a serem combatidos. Era comum à época, não somente ao teatro, a representação de cenas de esquartejamentos, torturas e grandes massacres. Todos esses recursos tentavam demonstrar subliminarmente que os sentidos eram diabólicos, que a vida terrena era ilusória e habitada pela morte e que, respectivamente, a salvação só era possível pela mediação da Igreja, traços que acabaram se tornando a essência da dramaturgia barroca da Alemanha católica ou mesmo protestante em autores como Opitz (1597-1639), Gryphius (1616-1664), Lohenstein (1635-1683) e Hallmann (1640-1704).

Optiz foi o formulador de uma nova poética de temas que destacavam os incestos, parricídios, incêndios e envenenamentos. Apesar de tipicamente barroco ainda seguia moldes classicistas, que iriam provocar a maioria dos equívocos na distinção do drama barroco da tradição da tragédia grega e renascentista. Gryphius, por sua vez, não esconde sua influência clássica, aliando o conhecimento do teatro de Moliére e Corneille da França e da Commedia dell'Arte italiana aos temas de fugacidade da vida e da exaltação do martírio a partir da experiência histórica marcante da Guerra dos Trinta Anos. Lohenstein também ficará fortemente marcado pela violência da guerra. Suas peças são as de tendências a cenas mais cruéis, de personagens macabros e de torturas monstruosas. Hallmann, por outro lado, prenuncia o Arcadismo ao apresentar elementos mais pastorais e operísticos, mas é significativo ao ser influenciado pelas festas das cortes do período barroco e sua multiplicidade de manifestações artísticas como a pintura, a arquitetura, a poesia e a música.

A partir da análise da literatura desses autores, Benjamin argumenta ainda que o conceito de Spiel (jogo, folguedo, espetáculo) dos dramas barrocos sofrerá diferenciações ao longo dos períodos artísticos: barroco, clássico e romântico. "No primeiro, há uma relação (da natureza de espetáculo, Spiel) predominante com o produto, no segundo com a produção, e no terceiro com ambos." E enfatizando a conceituação barroca do termo Spiel, destaca que...

\footnotetext{
a concepção da própria vida como um espetáculo, e que portanto deve designar como tal a obra, é alheia ao classicismo. (...) Elas (as peças do drama barroco) podem ser "alegres", embora a vida seja "séria", mas só podem ser lúdicas quando, em face de uma preocupação intensa com o absoluto, a própria vida perdeu a seriedade última. ${ }^{44}$
}

Benjamin vai utilizar o termo Trauer de maneira decisiva na diferenciação entre o drama barroco (Trauerspiel) e a tragédia clássica (Tragödie). Retomando a "Poética" de Aristóteles, Benjamin mostra que é inconsistente a equiparação dos dois gêneros pelos críticos de sua época. Segundo ele, os defensores da equiparação entre tragédia e drama barroco deveriam ter achado estranho que "Aristóteles nada dissesse sobre o luto

\footnotetext{
${ }^{44} O D B$. p. 105 .
} 
como ressonância do trágico" 45 . A tragédia provoca nos espectadores o efeito catártico da piedade e do terror, mas de modo algum provoca o luto. Já as peças do drama barroco destinam-se "a produzir no espectador uma emoção de luto", ou ainda, "estão a serviço da descrição do luto". São peças "graças às quais o luto encontra uma satisfação: peças para enlutados" "46.

$\mathrm{Na}$ tragédia grega há sempre uma perspectiva cósmica de julgamento divino dos espectadores. As cenas se transformam em tribunais que "diante de uma instância mais alta" ${ }^{47}$ avaliam as ações humanas. Diferente do drama barroco, para Benjamin, o que se passa na tragédia...

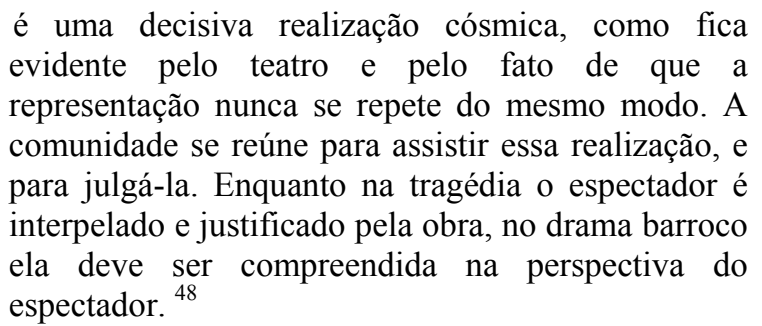

Esta compreensão das peças barrocas pelo espectador é facilitada porque "certa ostentação lhes é inerente" 49 . O drama barroco alemão, comenta Benjamin, "emergiu da pura ostentação, ou seja, dos trionfi, as procissões acompanhadas de recitativos destinados a explicar a ação, surgidas em Florenza sob Lorenzo de Medici" 50. A palavra Trauer associada a outras produz diversas composições que exprimem a conexão entre o luto e esta ostentação. Assim, temos: Trauerbühne ou Trauergepränge e Trauergerüst, em sentido figurado, significam a terra como palco para episódios tristes e literalmente significam a armação coberta com pano, as decorações e os símbolos utilizados para a exposição do corpo morto de uma pessoa ilustre ${ }^{51}$.

A necessidade de compreensão, caracterizada pelos elementos de ostentação monárquica das peças barrocas, criaram um "ritual" de representação de certo tipo de poder caracterizado pelo modelo absolutista. "O soberano representa a história. Ele segura em suas mãos o acontecimento histórico, como se fosse um cetro", comenta Benjamin, ao relacionar a finalidade do drama barroco com a formação, a partir da figura do tirano, de um novo conceito de soberania no século XVII ${ }^{52}$. Mais uma vez na história, a estética estava a serviço da política, contribuindo desta vez para a instituição da esfera pública do absolutismo e para a legitimação de seu poder.

A "encenação da melancolia" (o Trauerspiel) era uma forma de expressão de um pessimismo oficial, um pessimismo de estado. Benjamin comenta que havia um "interesse apaixonado pela pompa, nas "ações principais e de Estado"" 53 e que esta ostentação possuía uma magnífica afinidade com o luto. A pompa da autoridade e a solenidade hierática eram características de um espetáculo que visava à persuasão. A

\footnotetext{
${ }^{45} O D B$. p. 141.

${ }^{46}$ ODB. p. 142 .

${ }^{47}$ Ibidem. p. 142.

${ }^{48}$ Ibidem. p. 142.

${ }^{49}$ Ibidem. p. 142.

${ }^{50}$ Ibidem. p. 142.

${ }^{51}$ Cf. $O D B$. p. 143.

${ }^{52}$ Cf. $O D B$. p. 88.

${ }^{53}$ ODB. p. 163.
} 
"repetição infinita (das ações de luto e de rigidez contemplativa do Estado) ajuda os humores melancólicos, com seu desinteresse pela vida, a consolidar seu domínio" 54 . O luteranismo, religião da burguesia e de grande parte dos autores barrocos, segundo Benjamin, conseguiu "instilar no povo uma estrita obediência ao dever, mas entre os grandes instilou a melancolia" 55 . Deste modo, há uma intensa promoção, por parte das autoridades eclesiásticas e políticas, de uma patologia oficial ${ }^{56}$, configurada na "anestesia das paixões", na apateia, na "mortificação do corpo" e no taedium vitae. A Reforma religiosa promoveu a "crença sombria na sujeição do homem ao destino" assim, "as ações humanas foram privadas de todo valor. Algo de novo surgiu: um mundo vazio" 57 .

\section{Antíteses sem síntese: a subjetividade melancólica}

Certamente se o período barroco pudesse ser expresso em única imagem esta imagem, seria a da gravura Melencolia I de Albert Dürer. Para Benjamin, ela antecipa sob vários aspectos o Barroco. Nas suas palavras:

\footnotetext{
É consistente (...) que em torno do personagem de Albert Dürer, na Melencolia, estejam dispersos no chão os utensílios da vida ativa, sem qualquer serventia, como objetos de ruminação. (...) Nela, o saber obtido pela ruminação e a ciência obtida pela pesquisa se fundiram tão intimamente como no homem do Barroco. ${ }^{58}$
}

A meditação, a ruminação, a auto-absorção eram elementos característicos da subjetividade do período barroco. Uma subjetividade voltada ao luto e a melancolia. Benjamin escreve que a ênfase barroca na melancolia compôs "o estado de espírito do tempo". 59 No entanto, ressalta que esta "disposição melancólica" poderia levar facilmente as pessoas, através das suas auto-absorções, para "um abismo sem fundo" ${ }^{60}$. Este abismo estava presente no sentimento da época de que perante o implacável drama da história todas as criaturas eram extremamente frágeis.

O Renascimento e o protestantismo ocasionaram uma série de modificações de perspectivas. Muitas certezas sobre o mundo foram seriamente abaladas pelas descobertas cientificas, pelo racionalismo e pelo antropocentrismo da época. Dessa maneira, esse momento histórico carregado de desconfiança e até de pessimismo legou ao Barroco uma subjetividade voltada para a melancolia e para uma eterna sensação de luto. É no Barroco que este sentimento de luto potencializa-se, pois aqueles que vivenciaram esse período se vêem diante de uma existência horrorizada pela morte, pela ameaça da finitude e pela aflição da falta de transcendência. Como nas peças do drama barroco alemão, no período que sucedeu ao Renascimento, e que muito se assemelha ao

\footnotetext{
${ }^{54}$ Ibidem. p. 163.

${ }^{55}$ ODB. p. 204.

${ }^{56}$ Cf. BOLLE, Willi. Fisiognomia da Metrópole Moderna. p. 118.

${ }^{57} O D B$. p. 162.

${ }^{58} O D B$. p. 164

${ }^{59}$ Ibidem. p. 164.

${ }^{60}$ Cf. $O D B$. p. 165.
} 
nosso tempo, tudo acaba com a morte, com a chacina e a catástrofe. O sentido da vida se esvazia e o que fica é impotência. Tudo culmina com a morte como desfecho final e se desenrola na melancolia enquanto morte em vida, como vazio de sentido.

Aproximadamente na mesma época em que Benjamin trabalhava com estas questões sobre a subjetividade melancólica e de luto do Barroco, Freud escreve e publica Luto e Melancolia (1917) apresentando sutis distinções entre o significado de luto (Trauer) e de melancolia (Melancolie) utilizados por Benjamin. Freud inicialmente compara o processo da melancolia ao processo do luto. Para ele o luto "é a reação à perda de um ente querido, à perda de alguma abstração que ocupou o lugar de um ente querido, como o país, a liberdade ou o ideal de alguém, e assim por diante" ${ }^{61}$. Por sua vez, a melancolia refere-se à "uma perda de natureza mais ideal" 62.

O luto seria uma incapacidade de substituir aquilo que se perdeu. Uma perda que é incorporada ao próprio sujeito, fazendo recair sobre si todas as relações que possuía com o objeto amado, e até mesmo, o sentimento de ser ele próprio um objeto ausente. Desta maneira a fica a lacuna deixada pelo objeto que termina por ser o vazio do próprio eu. O sujeito passa a identificar-se como sendo o próprio objeto perdido. Por sua vez, a melancolia é comparada por Freud como sendo um tipo específico de luto, o luto pela perda da própria libido, a perda da vontade própria. A melancolia, assim, é colocada como um sentimento em relação ao luto por algo perdido. Nessa perspectiva, tanto ao luto quanto à melancolia uma noção de perda se faz presente, porém, enquanto no luto a perda se refere a um objeto externo, na melancolia a perda é relativa ao interesse pelas coisas e pelo mundo. É a perda da própria libido, daquilo que motivava à realização das atividades do indivíduo, o que explica a aparente preguiça do melancólico, a sua apatia. Freud observa que:

"No luto é o mundo que se torna pobre e vazio; na melancolia, é o próprio ego. O paciente representa seu ego para nós como sendo desprovido de valor, incapaz de qualquer realização e moralmente desprezível. " 63

Na melancolia ocorre uma diminuição da auto-estima ${ }^{64}$, um desaparecimento gradual do eu, uma perda de si mesmo. Não é simplesmente a desistência de um objeto desejado, é a transformação do próprio desejo em uma forma de conformar-se diante da impossibilidade de satisfação.

Apesar desta aparente morbidez da libido, da constante imobilidade do melancólico, ainda assim, a melancolia diferencia-se essencialmente do estado caracterizado pela psicanálise como depressão. A depressão é a queda do sujeito a um estado de luto patológico e permanente. Neste estado o sujeito não possui mais nenhuma capacidade de atribuir sentido ao mundo, a capacidade de substituir o objeto morto por outro. Por sua vez, na melancolia o que deprime, o que foi irremediavelmente perdido, não foi um objeto concreto, mas uma representação incerta dele em determinado momento da vida. Esta representação incerta ocasiona uma ambivalência de sentimentos. A busca pelo objeto ausente ora resulta um comportamento de retraimento e auto-absorção ora motiva a tentativa de vingança pela perda. Nisto reside uma importante ambigüidade do sentimento melancólico: o sujeito é empurrado a

\footnotetext{
${ }^{61}$ FREUD, Sigmund. Luto e Melancolia. p. 249.

${ }^{62}$ Idem, p. 249.

${ }^{63}$ Idem, p. 251

${ }^{64}$ Idem, p. 251.
} 
procurar o seu objeto e, ao mesmo tempo, é consciente de que está impossibilitado de achá-lo. Sua personalidade oscila entre o ímpeto criativo e a animosidade, entre a ação e a hesitação.

Esta ambigüidade possibilita à melancolia uma valorosa e peculiar condição de força crítica, conforme observa Benjamin:

\begin{abstract}
De fato, entre as intenções contemplativas ela (a melancolia) é a mais própria da criatura, e há muito já se havia observado que sua força não era menor no olhar do cão que na atitude meditativa do gênio. 'Meu amo, é verdade que a tristeza não foi feita para os animais, e sim para os homens, mas se os homens se excedem nela, transformam-se em animais', diz Sancho a D. Quixote. ${ }^{65}$
\end{abstract}

Desta maneira, é muito comum observar o sentimento de melancolia sendo somente relacionado ao seu efeito paralisador, esquecendo-se assim de compreendê-la como um estado de alternância entre a tristeza profunda, muito próxima de um estado patologicamente depressivo, e um estado de impulso ativo, de transformação, de rebeldia radical e de luta. Para alguns comentadores da obra de Benjamin ${ }^{66}$, estes dois estados antagônicos são respectivamente caracterizados pelos quadros sintomáticos da acedia e da cólera. Sobre a acedia, a tristeza paralisadora da melancolia, Olgária Matos explica que...

\begin{abstract}
A tristeza é um perigo mortal; ela é a acedia que torna mudo, ela nasce da "preguiça do coração" e a engendra por sua vez "quando desespera em dominar a verdadeira imagem histórica, aquela que brilha de maneira fugidia”. É a acedia, a tristeza, a falta de coragem que levava o historiógrafo a entrar em empatia com o vencedor, a se reunir ao cortejo triunfal dos espólios históricos. ${ }^{67}$
\end{abstract}

Por outro lado, contrapõe-se cólera como a antítese do estado de acedia. O sentido do termo colérico, na sua própria constituição etimológica, dimensiona o estado ativo e impulsionador da melancolia. ${ }^{68}$ A palavra "Melancolia" origina-se no grego, melankholia, combinação dos termos melanos (negro) e kholé (bílis) e designava originalmente os estados patológicos do fígado, onde se produziam fortes crises (as cólicas), mal-estar, tristeza e, por fim, um estado de constante irritação (cólera). O portador dessa doença também é conhecido como atrabiliário, palavra de origem latina que significa exatamente "aquele cujo organismo está tomado pela bílis negra". A melancolia, numa perspectiva de força crítica...

\footnotetext{
${ }^{65}$ ODB. p. 169. (Grifos nossos)

${ }^{66}$ É o que podemos encontrar principalmente na obra Walter Benjamin: o marxismo da melancolia de Leandro Konder.

${ }^{67}$ MATOS, Olgária C. F. O Iluminismo Visionário: Benjamin, leitor de Descartes e Kant. p.27. Os grifos são nossos e as citações no interior da citação são da tese VII de "Sobre o Conceito de História" de Walter Benjamin.

${ }^{68}$ Cf. KONDER, Leandro. Walter Benjamin: o marxismo da melancolia. p. 102.
} 
"precisava ser uma melancolia na qual reaparecia o elemento desaparecido da acepção original do termo: a cólera, a indignação dos justos. (sem a dimensão patológica que esse sentimento tinha nos 'atrabiliários')." 69

Benjamin também vai recorrer aos conhecimentos astrológicos da Antigüidade para demonstrar a natureza alternante da melancolia. Para ele, a teoria da melancolia está estreitamente associada à doutrina das influências astrais. Dentre os diversos astros que caracterizam a personalidade do melancólico, a influência mais fatídica é a de Saturno:

(...) a meditação do melancólico é compreendida na perspectiva de Saturno, que 'como o planeta mais alto e o mais elevado da vida cotidiana, responsável por toda contemplação profunda, convoca a alma para a vida interior, afastando-se das exterioridades, leva-a a subir cada vez mais alto e enfim inspira-lhe um saber superior e o dom profético'. ${ }^{70}$

Ocorre que Saturno, o astro "responsável por toda contemplação profunda" também é o deus dos extremos. Escreve Benjamin que, "por um lado, ele (Saturno) é o senhor da Idade de Ouro... por outro, é o deus triste, destronado e humilhado...". 71 Para a astrologia, um dualismo intenso e fundamental vai marcar a característica daquele que é influenciado por Saturno. Essa alternância de estados é o que, segundo Benjamin, torna fascinante as interpretações da doutrina desse astro e o liga "surpreendentemente" ao conceito grego de melancolia ${ }^{72}$. Benjamin utiliza o estudo de Panofsky e Saxl sobre a obra Melencolia I de Dürer para descrever o que ele, no que diz respeito à alternância antitética de estados da melancolia, convencionou por "dialética de Saturno":

Essa extremitas que em confronto com os três outros temperamentos tornou a melancolia, nos séculos seguintes, tão significativa e tão problemática, tão invejável e tão sinistra... dá também seu fundamento a uma decisiva correspondência entre a melancolia e Saturno... Como a melancolia, também Saturno, esse demônio das antíteses, investe a alma, por um lado, com a preguiça e a apatia, por outro com a força da inteligência e da contemplação; como a melancolia, ele ameaça sempre os que sejam, com os perigos da depressão ou do êxtase delirante... ${ }^{73}$

\footnotetext{
${ }^{69}$ Idem, p. 105. (grifos nossos)

${ }^{70}$ ODB. p. 171.

${ }^{71} O D B$. p. 172.

${ }^{72}$ Cf. expusemos anteriormente a palavra "Melancolia" origina-se no grego, Melankholia, combinação dos termos Melanos (negro) e Kholé (bílis). Respectivamente, a tristeza e a cólera da bílis negra.

${ }^{73} O D B$. p. 172.
} 
O dom profético, a força da inteligência e da contemplação, a alternativa crítica colérica torna visível outro aspecto da melancolia: sua relação com a verdade e com o método. Segue que, o melancólico é aquele que "medita sem fim" que contempla profundamente o vazio do mundo e a efemeridade de tudo, das coisas e das criaturas e destas transformadas em coisas por não terem mais sentido. O sujeito essencialmente influenciado por Saturno passa a preferir essas imagens àquelas que recorrem a um mundo de aparente beleza (Schein) e de infinitas possibilidades. Nisso reside a verdade que somente a melancolia expressa. Freud escreve sobre o sujeito melancólico:

\begin{abstract}
Quando, em sua exacerbada auto-crítica, ele se descreve como mesquinho, egoísta, desonesto, carente de independência, alguém cujo único objetivo tem sido ocultar as fraquezas de sua própria natureza, pode ser, até onde sabemos, que tenha chegado bem perto de se compreender a si mesmo; ficamos imaginando, tão-somente, por que um homem precisa adoecer para ter acesso a uma verdade dessa espécie. ${ }^{74}$
\end{abstract}

Ressalta ainda Freud, que só um homem doente "sustenta e comunica a outros uma opinião (crítica) de si mesmo como esta" 75 . Assim, o homem doente, um homem melancólico, é o portador de uma verdade sobre si mesmo e sobre o mundo (um mundo que como ele também aparenta estar doente) e que, por vezes, num ato de "êxtase delirante" ou de "febre colérica", a utiliza delatando a culpa que a humanidade parece esconder. Denunciando os culpados e expressando certas verdades, o melancólico trai o mundo para dar voz a uma atitude de questionamento da injustiça e da desordem numa original tentativa de ainda salvar as coisas. Nas palavras de Benjamin:

"De forma tosca e até injustificada, ela exprime, à sua moda, uma verdade, e por causa dela trai o mundo. A melancolia trai o mundo pelo saber. Mas em sua tenaz auto-absorção, a melancolia inclui as coisas mortas em sua contemplação, para salvá-las." 76

A atitude do melancólico, desta maneira, é semelhante à atitude do filósofo proposta por Benjamin na suas "questões introdutórias de crítica do conhecimento" da obra Origem do Drama Barroco Alemão. Sua tarefa é a representação das idéias e a salvação dos fenômenos por intermédio da conceitualização. É no conceito que a verdade (a essência, a idéia) das coisas mortas e fragmentadas (os fenômenos) é salva. Frente a ameaça da finitude e da degeneração de tudo pelo tempo, a única perenidade possível se encontrará na memória, na reminiscência e na teorização realizada pelo filósofo/melancólico. O filósofo, imbuído de sentimentos melancólicos e em sua profunda contemplação, assemelha-se ao artista que junta os cacos de algo destruído e, por sua vez, morto, para com eles construir novas obras com novas significações, construir mosaicos. Benjamin observa que:

\footnotetext{
${ }^{74}$ FREUD, Sigmund. Luto e Melancolia. p. 252.

${ }^{75}$ Idem, p. 252.

${ }^{76}$ ODB. p. 179.
} 
(...) ao considerar um mesmo objeto nos vários estratos de sua significação, ela (a contemplação) recebe ao mesmo tempo um estímulo para o recomeço perpétuo e uma justificação para a intermitência do seu ritmo. Ela não teme, nessas interrupções, perder sua energia, assim como o mosaico, na fragmentação caprichosa de suas partículas, não perde sua majestade. Tanto o mosaico como a contemplação justapõem elementos isolados e heterogêneos, e nada manifesta com mais força o impacto transcendente, quer da imagem sagrada, quer da verdade. ${ }^{77}$

O filósofo/melancólico, muito longe de deixar o mundo ao seu próprio ritmo de destruição e, ainda que vitimado por uma ilusão de que a transcendência era possível, tenta salvar as coisas da mesma maneira que tenta superar a perda ideal que gerou sua melancolia. Assim ele vai formando os conceitos, continua teorizando e produz filosofia, como maneira de preencher o seu vazio, o vazio da verdade que encontrou.

\section{Hamlet, Príncipe melancólico}

A polissemia em torno do termo Trauerspiel (o luto, a melancolia, a tristeza, acrescidos de espetáculo, jogo, encenação), sugere que o drama barroco era a peça, por excelência, promotora da melancolia, característica esta, oriunda da concepção de história mantida pelo Barroco. Essa concepção histórica retoma uma postura medieval caracterizada pela fuga do mundo e desvalorização da vida mundana e adapta-os a necessidades seculares do Estado Moderno, substituindo assim a perspectiva da história da salvação (de fundamentação originariamente cristã) por uma visão da história como a história natural, a história como o "percurso desolador da crônica do mundo" 78 . Decorre que, assim como no cotidiano, a naturalização da história provocou no drama barroco alemão, conseqüentemente, uma visão de fatalismo e de desesperança em relação à vida:

\footnotetext{
A linguagem formal do drama barroco, em seu processo de formação, pode perfeitamente ser vista como um desenvolvimento das necessidades contemplativas inerentes á situação teológica da época. (...) o drama alemão mergulha inteiramente na desesperança da condição terrena. Se existe redenção, ela está mais no abismo desse destino fatal que na realização de um plano divino (...). ${ }^{79}$
}

\footnotetext{
${ }^{77} O D B$. p. 50-51.

${ }^{78}$ Cf. BOLLE, Willi. Fisiognomia da Metrópole Moderna. p.113.

${ }^{79}$ ODB. p. 104.
} 
Entretanto, Benjamin enfatiza que "a fuga cega para uma natureza desprovida de Graça é especificamente alemã" ${ }^{80}$. Para ele, os dramas barrocos de outros países europeus, ao exemplo da Espanha, conseguem criar soluções para amenizar os conflitos e a desesperança resultante da ausência de toda escatologia de uma concepção de história salvífica:

\footnotetext{
Pois o drama da Espanha, o mais perfeito da Europa, e que desenvolve, nessa cultura católica, traços barrocos muito mais brilhantes, mais característicos e mais bem-sucedidos, consegue resolver os conflitos resultantes de um estado de Criação destituído de graça (...). ${ }^{81}$
}

Assim, dramaturgos como Calderón na Espanha e, ao seu tempo, Shakespeare na Inglaterra, superam em muito os dramaturgos barrocos alemães ao utilizarem artifícios que exploram o "jogo e a reflexão" em suas peças. Através do jogo e do constante incitamento à reflexão, o panorama melancólico da subjetividade barroca, que se alterna entre estados antagônicos, possibilita vigorosa força crítica. É através do olhar melancólico que o Barroco criou um estado de espírito de eterno luto. Entretanto, é através desse mesmo olhar que outra descrição do mundo pode ser elaborada. Benjamin notaria que, "é também à melancolia, que se apodera dos homens entre calafrios de terror, que os eruditos atribuem as manifestações que acompanham obrigatoriamente o fim dos déspotas" 82 .

Benjamin descreve o fato de o escritor barroco espanhol Calderón utilizar meios para a introdução da transcendência em seus enredos. Com a utilização da transcendência no palco, a descoberta da ilusão de transcendência da realidade se torna visível. Segundo Benjamin, um dos meios mais eficazes para a introdução da noção de transcendência no drama é a utilização de cenas de sonhos. Estas, por sua vez, possibilitam os melhores exemplos "da exatidão com que se harmonizam a dimensão da Trauer (luto) e a do Spiel (jogo)" 83.

Afirma Benjamin que,

(...) o sonho se estende sobre a vida desperta como a abóbada celeste. No sonho, a moralidade não perde os seus direitos: 'Sonho ou verdade, pouco importa. Devo fazer o bem, de qualquer modo. Se fosse verdade, deveria fazê-lo, por ser verdade; se fosse sonho, para angariar amigos, quando chegar a hora de despertar. ${ }^{84}$

\footnotetext{
${ }^{80}$ Idem, p. 104

${ }^{81}$ Idem, p. 104.

${ }^{82}$ ODB. p. 168.

${ }^{83}$ ODB. p. 105.

${ }^{84} O D B$. p. 104.
} 
E ainda destaca uma importante citação de Calderón a respeito do jogo:

\begin{abstract}
Assim como a vida dos mortais começa com folguedos infantis, ela termina igualmente com jogos efêmeros. Como Roma celebrou com jogos o dia em que Augusto nasceu, o corpo da vítima será sepultado com jogos e pompas... Sansão, cego, caminha, brincando, até seu túmulo; e nossa curta existência não é mais que um poema, uma peça em que uns entram e outros saem; com lágrimas ela começa, e com prantos acaba. Depois da nossa morte, o tempo costuma brincar conosco, enquanto os vermes devoram nossos cadáveres em decomposição. ${ }^{85}$
\end{abstract}

O jogo da vida é encenado no Trauerspiel, um "jogo da melancolia" ou, um "jogo do luto". O jogo como artifício de apreensão do espectador ao enredo das peças barrocas provoca uma dispersão do elemento de luto na obra de arte e causa uma "confrontação franca entre a perplexidade terrena do homem e o poder hierárquico do Príncipe..." 86.

Essa "perplexidade terrena" faz com que os heróis das peças de Calderón possam manipular a ordem de seus destinos e com essa "mudança de destino", auxiliada pelos artifícios de "miniaturização da realidade e a introdução no espaço fechado, finito, de um destino profano, de um pensamento reflexivo infinito" 87 provocam a constituição de intensa capacidade crítica. Nesse ponto situa-se a diferença essencial entre a tragédia clássica e o drama barroco. Enquanto o herói da tragédia antiga é ignorante de seu destino, sendo muitas vezes vitimado por ele, ao exemplo de Édipo que inevitavelmente acaba matando o seu pai e casando-se com a sua mãe, no drama barroco o personagem sabe da sua finitude e da finitude do mundo e por esse saber sente-se culpado e tenta, sem sucesso, expiar esta culpa.

No barroco, o mundo é o mundo das criaturas sofredoras no qual as leis do destino devem se impor, e todos, até mesmo o Soberano, sabem disso. Mas, certamente o melhor exemplo de utilização de personagens que possuem a consciência culpada de criatura finita, e de um mundo decadente e de injustiça vem de Shakespeare, mais exatamente de Hamlet.

Os tipos dramáticos do drama barroco alemão foram marcados por uma intensa religiosidade oriunda das transformações ocasionadas pela Contra-Reforma e, por sua vez, vinculadas ao Absolutismo. Estado e religião se confundem no Barroco. Entretanto, esta tipificação não é total. Graças às inovações renascentistas voltadas para as especulações, fruto do humanismo e do racionalismo, conseguiu-se descobrir um "reflexo de uma luz distante" cintilando na mais profunda "contemplação lacrimosa" 88. Assim, um escritor quase sempre considerado renascentista acaba revolucionando o drama Barroco com seus geniais personagens reflexivos. Através das peças de William Shakespeare (1564-1616), abre-se a possibilidade de fuga à tipificação estritamente religiosa do barroco e o melhor exemplo deste tipo dramático diverso é o personagem do príncipe Hamlet:

\footnotetext{
${ }^{85}$ Cf. $O D B$. p. 106.

${ }^{86}$ ODB. p. 107.

${ }^{87}$ ODB. p. 106.

${ }^{88}$ Cf. $O D B$. p. 179.
} 
Pelo menos uma vez a época logrou conjurar a figura humana correspondente à dicotomia entre a iluminação neo-antiga e a medieval, na qual o barroco via o melancólico. Mas não foi a Alemanha que conseguiu esse resultado. Foi a Inglaterra, com Hamlet. (...) No drama barroco, somente Hamlet é espectador das graças de Deus. ${ }^{89}$

A tragédia de Hamlet, o príncipe da Dinamarca, configura um sério depoimento sobre a condição humana e reflete uma sociedade em crise. O personagem do Príncipe, de imponente personalidade, é a que melhor exemplifica a alternância entre ação e hesitação na subjetividade melancólica. A esse respeito, destaca Benjamin que:

\begin{abstract}
O Príncipe é o paradigma do melancólico (...) 'Ele treme diante de sua própria espada (...) o exército do medo rasteja sorrateiramente, e vela em seu leito' (ou ainda) 'a triste melancolia em geral mora nos palácios'. (...) a imagem da corte não é muito diferente da imagem do inferno, que de resto foi chamado o lugar da eterna tristeza. ${ }^{90}$
\end{abstract}

Por outro lado, a figura de príncipe auto-reflexivo consegue superar a acedia, a melancolia que anestesia as paixões e imobiliza as ações humanas, uma figura comum ao obscurantismo medieval, e consegue chegar a uma espécie de cristianismo que diminui a rigidez barroca. "Só numa vida como a desse Príncipe a melancolia pode dissolver-se, confrontando-se consigo mesma." "91. Shakespeare, através de Hamlet, consegue atribuir valores cristãos à dura imagem do soberano barroco absolutista.

O tema da vingança na peça de Shakespeare sobre o Príncipe da Dinamarca é outro aspecto que faz melhor aparecer a ambivalência da subjetividade na presença da melancolia. A missão de Hamlet de vingar a morte de seu pai e arrancar do trono seu tio Cláudio, o assassino, uma incumbência que lhe foi transmitida pelo próprio morto, sob a forma de fantasma, provoca nesse personagem o estado único de um homem que passa a se investigar, se analisar, hesita antes de agir, reflete sobre seus atos e sobre o sentido da existência. Dessa maneira, Hamlet, do mesmo modo que a natureza melancólica que o influencia, oscila entre dois extremos. A fim de dar conta das situações externas e implantar um reino estável, ele precisa lançar mão de poderes ditatoriais; no entanto, ao encarnar a lei da criatura e a sujeição à morte, ele é inevitavelmente levado a acatar a própria condição de mártir. ${ }^{92}$ Sobre esse aspecto escreve Benjamin que:

Ao "inteiramente mau" correspondem o drama do tirano e o terror, e ao "inteiramente bom", o drama do mártir e a piedade. (...) Se levarmos em conta os

\footnotetext{
${ }^{89}$ Ibid., p. 179.

${ }^{90}$ ODB. p. $165-68$

${ }^{91} O D B$. p. 180.

92 Cf. BARROS, Fernando de Moraes. "Ser ou não ser”: a melancolia e a representação pública do poder na Origem do Drama Barroco Alemão. p. 33.
} 
ensinamentos da ideologia, tais formas são rigorosamente complementares. Para o Barroco, o tirano e o mártir são as faces de Jânus do monarca. São as manifestações, necessariamente extremas, da condição principesca. ${ }^{93}$

Diferentemente dos heróis trágicos, que encaram o drama da morte e entregam seu nome à posteridade, Hamlet, o Príncipe barroco da Dinamarca, não tem no final a mesma resolução, o mesmo momento de completude no qual se realizará todo o seu destino e do qual nos fornecerá alguma lição. Não há imortalidade, transcendência e uma ação que possa se convencionar exemplar. A vingança de Hamlet somente se consuma após uma sucessão de mortes (inclusive a própria morte de Hamlet), de supostas loucuras e da busca pelo sentido disso tudo.

Deste modo, a peça de Shakespeare encerra sem qualquer possibilidade de transcendência. Ao final não há uma verdade a ser revelada, não se descobrem os impostores, não há certezas sobre aquilo que moveu a trama toda desde o início. Manifesta-se assim uma verdade sem verdade, só com objeções e considerações de maneira que o expectador é obrigado a permanecer sempre a procurar um sentido final, fato que talvez explique as muitas teorias que surgiram para explicar esta peça ${ }^{94}$. Por fim, esta verdade "sem algo definitivamente verdadeiro", uma espécie de "verdade da imanência" e a cuja busca incessante o melancólico se submete, é uma verdade que somente a alegoria poderia produzir.

\section{Referências Bibliográficas}

1. ADORNO, Theodor W; HORKHEIMER, Max. Dialética do Esclarecimento: Fragmentos Filosóficos. Tradução de Guido Antonio de Almeida. Rio de Janeiro:

\footnotetext{
${ }^{93}$ ODB. p. 93.

${ }^{94}$ Cf. observações na introdução de uma das traduções de Hamlet para o português, cerca de 80.000 volumes de trabalhos já foram escritos tentando analisar o mundo das paixões e desencantos em que se insere a tragédia do príncipe da Dinamarca. p. 17.
} 
Jorge Zahar Ed., 1985.

2. ARENDT, Hannah. Homens em Tempos Sombrios. Tradução de Denise Bottmann. Posfácio de Celso Lafer), São Paulo: Companhia das Letras, 1987.

3. BARROS, Fernando de Moraes. "Ser ou não ser": a melancolia e a representação pública do poder na Origem do Drama Barroco Alemão. In: Cadernos de Ética e Política. no 5, São Paulo: Humanitas Livraria - FFLCH/USP, 2002.

4. BENJAMIN, Walter. Origem do Drama Barroco Alemão (Tradução, apresentação e notas de Sérgio Paulo Rouanet), São Paulo: Brasiliense, 1984.

5. BOLLE, Willi. Fisiognomia da Metrópole Moderna. Representação da História em Walter Benjamin. São Paulo: EDUSP, 2000.

6. BUCK-MORSS, Susan. Dialética do Olhar. Walter Benjamin e o Projeto das Passagens. Tradução de Ana Luiza de Andrade. Belo Horizonte: Editora UFMG; Chapecó: Editora Universitária Argos, 2002.

7. CHAVES, Ernani. No Limiar do Moderno: Estudos sobre F. Nietzsche e W. Benjamin. Belém: Paka-Tatu, 2003.

8. EAGLETON, Terry. O Rabino Marxista: Walter Benjamin. In: A ideologia da estética. Rio de Janeiro: J. Zahar, 1993.

9. FREUD, Sigmund. Luto e Melancolia (1914). In: Obras Completas. Vol. XIV (1914-1916). Rio de Janeiro: Imago, 1969.

10. GAGNEBIN, Jeanne-Marie. Por que um mundo todo nos detalhes do cotidiano? História e Cotidiano em Walter Benjamin. In Dossiê Walter Benjamin. Revista USP. $\mathrm{N}^{0}$ 15. São Paulo: EDUSP, 1992.

11. KONDER, Leandro. Walter Benjamin - O Marxismo da Melancolia. Rio de Janeiro: Campus, 1988.

12. MATOS, Olgária Chain Féres. O Iluminismo Visionário: Benjamin, leitor de Descartes e Kant. São Paulo: Brasiliense, 1993.

13. SHAKESPEARE. William. Hamlet. Tradução de Péricles Eugênio da Silva Ramos. São Paulo: Abril Cultural, 1976.

14. VIEIRA, Antônio. As lágrimas de Heráclito. São Paulo: Editora 34, 2001. 